\title{
Storytelling in Crisis Communication
}

\section{Tuğçe Ertem Eray, University of Oregon, USA}

\begin{abstract}
Stories are effective communcation tools because there are no one who doesn't like them. When a story is heard or listened, it can be a powerful communication tool to awake people's emotions. Therefore organizations should use storytelling as an effective communication tool. Stories and storytelling are central parts of organizational life, shaping corporate culture and influencing corporate behavior. They help facilitate knowledge sharing, and solve problems and make decisions. They can have an effect on public's opinion about the organizations. Stories have so many functions in organizations as a communication mechanism and one of them is to deal with crises. There are seven types of storytelling which are used in organizations. This study considers the one which is about how organizations deal with obstacles and aims to prove that storytelling can be used as a communication tool during a crisis. For this, examples are given to understand the current usage of storytelling in crisis communications.
\end{abstract}

Keywords: Stories, Storytelling, Crisis, Crisis Communication 


\section{Introduction}

"Without air, our cells die.

Without stories, our selves die."

Neil Postman

Stories are familiar to all humans, we all grow up with stories and hear them in our lifetimes; and nowadays stories are used as a communication tool for organizations. They are one of the latest management trends in organizations and play an enormous role in organizations, management, communication, etc. Communication has become the watchword of all organizations and functional areas during the past decade and in line with this, new concepts have emerged in the literature about corporate and marketing communications, like branding, integrated communication, storytelling. These concepts seek to inpire confidence by reducing risks and complexity in the internal and external conditions of the organization concerned (Langer / Throup 2006, p. 374). Kaufman (2003, p. 1) specified that researchers have found storytelling to be far more convincing to organization's publics than rational arguments, statistics or facts. Stories make a topic much more real to the public than the most rational persuasion because it reframes the argument in an esay-to-grasp format anyone can relate to. McKee and Fryer (2003) stated that there are two ways to persuade people and one of them is uniting an idea with an emotion. The best way to do that is telling a story. Telling a story not only weave a lot of information into the telling but also arouse the listener's emotions and energy. Denning (2011, p. 6) emphasized that the management fads may come and go, yet storytelling is fundemantal to all nations, societies and cultures and has been so since time immemorial. And not just leaders in business and politics use the stories. Anyone who has a new idea and wants to change the world can do it by telling stories. Stories can be used also to communicate the company's messages internally and externally.

Storytelling can be applied in a variety of contexts as a communication tool (Fog, et al. 2010, p. 54). Organizations can create meaning among publics by telling a good story that transmits what the organization stands for and the values that it embraces. Well-told stories have the potential to evoke emotions and dreams, by doing that organizations can communicate with their publics in a more efficient way (Lilijander, et al. 2011). Besides Kopp, et al. (2011, p. 373) emphasized that the literature is still growing on how the storytelling could be helpful; not only how publics make sense of a crisis, but also how they adapt to the inevitable 
organizational changes following a crisis. Consequently it is thought that the concept of storytelling should also be a part of communication plans in crisis communication.

Development of new communication technologies causes the organizations to confront more serious problems in crisis situations. Hence, new concepts should be included in crisis communication. The power of story to defend organizations in social media should be considered. From this point of view, this study dwells on the utilization of storytelling in crisis communication and aims to understand the current use of stories in crisis.

\section{The Concept of Story and Organizational Storytelling}

Stories are evaluated as communications about personal experience told in everday discourse. "They are the reporting of experience in everyday conversation and when people narrate their experience, this means they project a story form onto that experience". Stories are defined as a form of knowledge and a medium of communication (Browning 1992, p. 285). O'Neill (2002, p. 5), defined the story, through drawing from the existing literature "a discourse which has been repeated by some organizational member to other organizational member(s) to fulfill some need, and which possesses a degree of color, evoking emotion in the listener(s), and resulting in some memorable quality regardless of whether the communication is based on actual events, is mythological in nature, or exists somewhere in between." Denning (2011, p.7), identified some propositions, that are not particularly controversial to most people, which are wrong, such as:

- "Storytelling is an ancient art that hasn't changed much in several thousand years.

- The effective use of storytelling in organization involves crafting and performing a well-made story with a hero or heroine, a plot, a turning point and a resolution.

- A storyteller catches and holds the attention of an audience by evoking the sights and sounds and smells of the context in which the story took place.

- A well-made story is effective regardless of the purpose for which the story is being told.

- Storytelling is a rare skill in which relatively few human beings excel."

Different narrative patterns are useful for different purposes, and knowing which one is suitable for which task is a key to the effective use of storytelling. Also, a story is about problems, solutions, explanations and often lacks a hero or heroine (Denning 2011, p. 8). 
Stories and storytelling are a central part of organizational life, shaping corporate culture and influencing corporate behavior. It is also a powerful management tool to facilitate knowledge sharing, help problem solving and decision making (James / Minnis 2004, p. 23). Liljander, et al. (2011) found that the consumers who were exposed to the story perceived the organization in much more positive terms. Stories which exist in organizations as a communication mechanism have many functions. They provide coherence to members of organizational subcultures, reduce uncertainty for organizational members, become sources for organizational knowledge, transmit organizational beliefs and generate commitment, guide or control organizational members' behavior, legitimize and reinforce power and political relations among organizational members, are a key part of members' organizational sense making, and assist with the socialization process for new organizational members (O’Neill 2002, p. 4-5).

Organizational stories can be created by leaders or co-created with organizational members and they are regarded as vehicles to expose the fundamental values of an organization. They are not only a form of communication in everyday organizational discourse, but also a tool for memorializing the historical events of organization (Kopp, et al. 2011, p. 374). Especially during the increase of interest in organizational culture in the 1980s, epic myths of the organization come to mind. It is stated that an epic myth generally focuses on events that are drawn from the organization's history, and if they are embraced by the members of the organization, they bond them together. The heroes of the story are generally leaders or founders of the organization and the story communicates the values of the main character who has become a symbolic, idealized role model. A typical story describes the hard situations the company faced at its birth, the huge struggle to keep the organization alive, personal sacrifices which were made by leaders of the organization and the achievement of unexpected success (James / Minnis 2004, p. 23-24).

Brown, et al. (2004) give an example of stories about the organization: Chemical Bank merged with another bank to form a new bank. But, at the time of this story it was a New York bank called the Chemical Bank. Their Chief Information Officer decided to try something different and put up a system called RumorMill because he knew that a lot of people were worried about what was going on. There were rumors going around and through this system, he responded to all questions about rumors within 24 hours. At first, he received about five inquiries and sent answers back. Next week he received about 100 inquiries such as "Are we merging with Chase?", "I heard we're going to go bankrupt. Is it true?", "Are we 
getting a new CEO?". He answered most of the questions, but sometimes he had to say that he was sorry that he wouldn't be able to answer because this was still secret information. Next week he received 4000 inquiries and he had to shut the systam down. The interesting thing about this experience is the evidence of the bottled-up need for information. If people don't know what is going on, they tell stories. Therefore, it can be said that organizations should tell their own stories. It is also the same in crisis situations; if organizations do not tell their stories in a crisis, publics will and this can make the crisis much more complicated. Therefore, utilization of storytelling as a new communication concept is essential to dealing with crisis.

Martin, et al. (1983, p. 439), presented seven types of corporate stories, one of which is about how organizations deal with obstacles. And from the point of our topic, these types of stories which are used by organizations to get through the crisis situations will be considered.

\section{Storytelling in Crisis Communication}

In the communication literature, studies about storytelling increase gradually, and there are studies which focus on how storytelling facilitates organizational members to understand crisis and to adopt themselves to organizational changes after crisis. Kopp, et al (2011, p. 373 , 374) emphasized that storytelling needs to be a part of the organizational crisis communication program. They told that storytelling can decrease the stress and negative feelings during the crisis. There has been much written about organizational storytelling's effect on organizational commitment, knowledge sharing, management development, organizational change, etc.; however, the literature on using organizational stories during crises is still a work in progress. Organizational crisis is stated as a predictable event and described as a inherent narrative, therefore Kopp, et al (2011, p. 376) explained that "the power of organizational storytelling lies within its narrative process, which can absorb discordance when constructing a plot around a disruptive occurrence. And organizational storytelling is especially suited as a crisis management tool specifically because of its sensemaking prescription of disruption-transformation-solution."

Fox, et al (2010, p. 111), said that in any company there are always events of special significance which have an important role in shaping the company and in determining its future. By examining these events, communicators can uncover stories, which are rich in value content. Especially when things go wrong and companies are in deep crisis, to uncover 
stories become so important. They stated a few tips for creating stories about company's significant events:

- "Start with senior employees or employees who have been with the company for many years and who know its history inside out.

- Ask about the times that the company has experienced its greatest crisis. How was the crisis overcome-and what does this say about the company's values?

- At any point in time has the company gone through a change in course? What prompted the change?

- When did the company experience its greatest successes? What happened?"

Stories operate to integrate the complex nature of organization practices and actions, and through the use of symbolism, they operate to resolve conflicting emotional dynamics and create a unique interpretation of reality (James / Minnis 2004, p. 24). Organizations claim they understand the problems of their customers, but saying so does not accomplish anything. Through a story, organizations apply their claims to the real world. Masterful storytelling shows the viewer/reader that the organization understands the problem and how their products solve it (DeMers 2014). There are some principles that are essential to engaging publics. Especially when passions are running high, communicators should know the followings:

- "Tell personal stories. Make it easier for your audience to relate to your mission by putting the focus on the people you're impacting.

- Listening is half the battle (and often more). Particularly in times of crises and debate, listening to constituents and showing empathy are bridges to understanding.

- Reach people where they are. Digital and social media allow us to communicate across myriad channels where our audiences are. Go to them and make sure to engage people on platforms native to them." (Leslie / Shandwick 2015).

Melissa Agnes (2014), who is a crisis management strategist, discussed the power of storytelling in crisis communications with Greg Power, President of Weber Shandwick Canada. They said that a powerful story told by an organization can save the organization from an otherwise irreparable crisis. Organizations need to develop empathy with the public that matters to them and to take control of narratives in crisis situations. Power advised that organizations should tell a story in crisis; they should not organize press conferences, answer questions and provide informations that people can make a story of. They should turn the 
situation into a dramatic narrative because it is the best format for organizations to share that story. Organizations should provide a story if they want to be understood in their own terms. In crisis, the important things are: how organizations handle the crisis situation, if they do the right thing when a crisis hit them and if they empathize that they care about the people who were hurt by that crisis. Power emphasized that people understand because they know that everybody makes mistakes, even organizations. Therefore organizations need to be transparent and tell their stories to their publics, and also they need to understand their publics thoroughly in order to reach them.

McKee and Fryer (2003) explained that "Most companies and executives sweep the dirty laundry, the difficulties, the antagonists, and the struggle under the carpet. They prefer to present a rosy — and boring — picture to the world. But as a storyteller, you want to position the problems in the foreground and then show how you've overcome them. When you tell the story of your struggles against real antagonists, your audience sees you as an exciting, dynamic person. And I know that the storytelling method works, because after I consulted with a dozen corporations whose principals told exciting stories to Wall Street, they all got their money."

Crisis communication is also about the protection of corporate reputation. Therefore, stories should consider corporate reputation when they are used to deal with crises. Creating positive corporate reputation takes too many years whereas it is destroyed in less than two minutes, especially in social media. Özgül (2010, p. 56) rewrote the functions of the stories from the perspective of corporate reputation management. These functions can also be taken into consideration in terms of crisis communication management. Organizations desire to draw publics' attention through storytelling, and by doing this they desire to direct their attention to the company, product or hero. Complex thought about the company is simplified by means of storytelling and thus publics' needs are resolved in the fictional platform. Eventually, storytelling is the sum of values, symbols, heros and rituals. All these features mean shared values to the publics and draw them to the organizational structure. More importantly, all attempts about corporate reputation can be forgotten, while stories stick in public's mind more than written materials. 


\section{Types of Stories in Crisis Communication}

There are three types of stories that organizations tell: the story of the firm itself, stories of the firm's products or services, and customers' own stories and their relationship to the firm (Denning 2011, p. 113). Organizations can use all types in crisis communication. For example, the story of the firm itself was used by Johnson \& Johnson during Tylenol crisis. Johnson \& Johnson's story was told and retold, and Tylenol had become the most popular analgesic in the United States. In Turkey, Inoksan, a company in the kitchen industry, had its most significant crisis that spread via rumors. In 2012, they had financial crisis and couldn't pay dividends to their stakeholders. They had made all their payments on time thus far which amplified the magnitude of the crisis. Vehbi Varlık, who is a founder of Inoksan, explained how they overcame this crisis. They visited their customers one by one and made their payments after these visits. The most important thing that we did, he said, was to communicate face to face (Capital 2016). It can be stated that Inoksan told the company's story to their stakeholders for a year, and by doing this, they overcame the crisis. If they had not addressed this situation themselves and directly communicated to their stakeholders, this crisis would have been unsolved.

Second type was used by Mey Içki, a Turkish alcoholic beverages company, during the fake raki crisis in 2005. This type of story uses the invention or production of a product as its source of content. If the product has a long history, organizations have chances that can add value from the past to the product in the present (Fox, et al. 2010, p. 112). Mey Içki told journalists the differences between the real and fake raki. Company pulled all the products from the shelves all around the country and decided to redesign the bottles. Then it replaced the old bottles with the newly designed ones (Vatan 2016). After these strategic moves, company told stories about the importance of raki for Turkish people and these stories found a place in social media. Mey Içki (Diageo 2016) still is one of the top players in the alcoholic beverage market in Turkey and their brand of raki is the number one selling raki in the country.

Third type of stories are told by the customers. For example, in the advertisement of Varyap, actual customers play a role. A lawyer, a financial adviser and a national volleyball player told their stories about the reasons that they bought an office in this project (Marketing Türkiye, 2016). Nowadays, stories which are told by customers, employees are more 
important, trustworthy and realistic than the stories which are told by companies themselves. One example about the stories which are told by the employees is Akbank's commercial movie (Campaign Türkiye 2016). Real employees play a role in Akbank's corporate social responsibility advertisement. Akbank's employees voluntarily engage in different activities such as painting schools, visiting shelters, etc. The commercial tells the stories of these activities which are carried out with the help of Akbank's own employees.

Besides, this type of stories requires dialogue with the organization's customers. If organizations do not have such a dialogue, they need to consider ways to get direct feedback form the customers (Fox, et al. 2010, p. 119). Nowadays dialogue between organizations and its publics becomes an obligation because of the social media. Organizations need to have an account in social media sites to maintain their existence and need to communicate their publics through these accounts, especially in crisis. It is a fact that customers read the other customers' comments before purchasing products or utilizing services. Also, it needs to be considered that when a customer gets angry he/she can cause a huge crisis by using social media. In this sense, it is not to be forgotten that today, customer's own stories are the most common stories because of the Internet.

The development of communication technologies has changed the quality of the communication between organizations and its publics. Harvard Business Review emphasized in their cover quotation that customers know everything about the companies, so that has changed the rules of business forever. Stories are becoming so important, especially in social media, to tell the publics who the organization is (Denning 2011). Besides, it is important for customers to share their experience. Delgadillo and Escalas (2004) emphasized that when sharing a certain experience about a product or service, people normally communicate in the form of a story. Memory for story facts and the story gist affect the attitude of the listener towards the target of the story. Therefore, it can be stated that stories that the organization tells about the crisis are becoming less important than stories that publics tell. For example, in 2008 Howard Schultz, CEO of Starbucks, woke up one morning and found around a hundred e-mails in his inbox. These e-mails were the results of a sensational story in the Sun, a London newspaper, about a problem that Schultz hadn't heard. A reporter called and asked him to comment, Shultz told that he had no idea what it was. The reporter advised him to find out fast. Although the real-world issue in the story became insignificant, it had become an 
instant public relations crisis. Schultz recalls: "The lesson was that the world had changed. Something that happened in London had created a world-wide story that positioned Starbucks with venom and disrespect." Stories told by customers can instantly surpass the stories told by organization itself. The scale and rapidity of the public relations crises are amazing (Denning 2011, p. 110).

As we can see, storytelling becomes one of the most important communication tools for crisis management strategies, and organizations should tell their own stories to prevent the crisis from becoming more severe and irreparable.

\section{Conclusion}

Economical, cultural, social, and especially technological changes require organizations to consider their communication techniques. In the twentieth century, new concepts have emerged in the communication techniques of organizations about marketing, reputation management, crisis management etc. One of them is storytelling. In the communication literature, studies about storytelling increase gradually and we can find studies that focus on utilization of storytelling in crisis. Organizations use storytelling for their members to understand crisis and to adopt themselves to organizational changes after crisis. They also use storytelling for their publics to make crisis understandable, to solve the problems, to make their publics' mind clear, and to avoid losing their publics.

Storytelling today can be an effective tool for solving crisis and give a chance to organizations to explain themselves properly in crisis situations. Utilizing storytelling as a communication tool in a crisis can show to its publics the organization's struggles and how they handle crises. When organizations utilize storytelling in crisis, one of the most important things is to be as clear and transparent as possible. Organizations should tell the truth to their publics and they need to be mindful of them. By doing this, organizations can overcome crises succesfully and maintain their existence.

Today, any person or company can publish content on the Internet, especially in social media sites. Pulizzi (2012, p. 119) emphasized that whether the company's goals are rooted in getting found in search engines or leveraging social media tools, none of them will be effective without compelling storytelling. And organizations increasingly understand that all 
the technology tools are worthless without a storytelling strategy. Therefore, storytelling is a more effective, and more powerful strategy for organizations to manage their communication strategies; also to manage their crisis communication stategies. If customers tell a positive story about the organization, it can work in favor of the product or service. However, if customers tell a negative story about the organization, it works against the product or service. Thus, especially in today's world, because of the Internet, negative stories told by customers make crises more intense and unsolvable. Consequently, organizations need to interfere with these types of stories rapidly as a part of their crisis communication management strategy. Organizations have to take action to switch the negative stories into positive ones. Their stories can tell the organization's struggle and how they deal with a crisis. They can also tell their mission, position and history to their publics to repair their image and reputation. When doing this, they need to know exactly who their publics are in order to reach them, and they need to empathize with the people who suffered from that crisis.

Organizations can use all types of stories, as we discussed above, as a crisis management tool. The important thing is to decide which one is more appropriate for the crisis situation that organizations confront. Today, organizations should not disregard the power of the Internet and social media which are the most effective channels that enable organizations to tell their stories. Through social media, organizations tell their stories to millions of people when they deal with the crisis and by doing this properly, organizations protect their reputation, gain public's trust and can overcome crisis with minimum damage. 


\section{References}

Agnes, M. (2014). "The Cpower of Story Telling in Crisis Communications with Greg Power", 27 July 2014, retrieved 09.07.2016, from http://melissaagnes.com/tcip-008the-power-of-story-telling-in-crisis-communications-with-greg-power/.

Brown, J. S., Denning, S., Groh, K. \& Prusak, L. (2004). Storytelling in Organizations: Why Storytelling Is Transforming 21st Century Organizations and Management, Taylor and Francis, UK.

Browning, L. D. (1992). "Lists and Stories as Organizational Communication”. Communication Theory, 2, 281-302.

Campaign Türkiye, (2016). TBWA/İstanbul'dan duygusal Akbank reklamı, 11 April 2016, retrieved 06.07.2016, from http://www.campaigntr.com/2016/04/11/133381/tbwaistanbuldan-duygusal-akbankreklami/.

Capital, (2016). Unutulmaz kriz yönetimi. Retrieved 18.04.2016, from http://www.capital.com.tr/yonetim/basari-oykuleri/unutulmaz-kriz-yonetimihaberdetay-22056? sayfa=3.

Delgadillo, Y. \& Escalas, J. E. (2004). "Narrative Word-Of-Mouth Communication: Exploring Memory and Attitude Effects of Consumer Storytelling", in NA - Advances in Consumer Research Volume 31, eds. Barbara E. Kahn and Mary Frances Luce, Valdosta, GA : Association for Consumer Research, 186-192.

DeMers, J. (2014). "How to Maximize Your Marketing Campaign Through Storytelling”, 30 June 2014, retrieved 07.07.2016, from http://www.forbes.com/sites/jaysondemers/2014/06/30/how-to-maximize-yourmarketing-campaign-through-storytelling/\#2d0222651d30.

Denning, S. (2011). The Leaders's Guide to Storytelling: Mastering the Art and Discipline of Business Narrative, Jossey-Bass, San Francisco.

Diageo, (2016). Mey Icki Fact Sheet, retrieved 18.04.2016, from https://www.google.com/url?sa=t\&rct=j\&q=\&esrc=s\&source=web\&cd=1\&cad=rja\& uact=8\&ved=0ahUKEwiesNH90pjMAhUovIMKHTd2CXgQFggcMAA\&url=http\%3 A\%2F\%2Fwww.diageo.com\%2FLists\%2FResources\%2FAttachments\%2F736\%2FFI NAL\%2520mey\%2520factsheet.pdf\&usg=AFQjCNFaVhr97pA936EGWJvVXgHVH iPxgw\&sig2=bCQAAOkPLTzZWFapaiMdSQ\&bvm=bv.119745492,d.amc. 
Fog, K., Budtz, C., Munch, P. \& Blanchette, S. (2010). Storytelling Branding in Practice, Springer, Denmark.

James, C. H. \& Minnis, W. C. (2004). “Organizational storytelling: It makes sense”. Business Horizons, 47/4, 23-32.

Kaufman, B. (2003). "Stories that Sell, Stories that Tell”, Business Strategy, March/April, 14.

Kopp, D. M., Nikolovska, I., Desiderio, K. P. \& Guterman, J. T. (2011). "Relaaax, I Remember the Recession in the Early 1980s...”: Organizational Storytelling as a Crisis Management Tool. Human Resource Development Quaterly, 22(3), 373-385.

Langer, R., Thorup, S. (2006) "Building trust in times of crisis Storytelling and change communication in airline company". Corporate Communication: An International Journal, 11(4), 371-391.

Leslie, J., Shandwick, W. (2015). "The power of innovative storytelling in solving global crises". December 18, 2015, retrieved 16.04.2016, from http://www.prweek.com/article/1377535/power-innovative-storytelling-solvingglobal-crises\#rpBXM0SSRJGqev4H.99.

Lilijander, V., Gummerus, J. \& Lundqvist, A. (2011). "Tell me a story and I will like your brand more". 10th International Marketing Trends Conference, 20-22nd January 2011, Paris, France.

Marketing Türkiye, (2012). Varyap reklamında müşteriler oynuyor, June 6, 2012, retrieved 04.07.2016, from http://www.marketingturkiye.com.tr/kampanya/varyap-reklamindamusteriler-oynuyor.

Martin, J., Feldman, M. S. \& Hatch, M. J. \& Sitkin, S. B. (1983). “The Uniqueness Paradox in Organizational Stories”. Administrative Science Quarterly, 28, 438-453.

Mckee, R. \& Fryer, B. (2003). “Storytelling That Moves People”, retrieved 07.07.2016, from https://hbr.org/2003/06/storytelling-that-moves-people.

O’Neill, J. W. (2002). “The Role of Storytelling in Affecting Organizational Reality in the Strategic Management Process”. The Journal of Behavioral and Applied Management, 4(1), 4-19.

Özgül, R. (2010). İtibar Yönetimi Çerçevesinde Öyküleme, Unpublished Doctoral Thesis, Marmara University, Istanbul, Turkey. 
Postman, N. (1994). "Learning by Story," Dialogues and Conversations: A Reader for English 115, ed. Grant Boswell and Gary Hatch, Needham Heights: Simon \& Schuster, p. 184.

Pulizzi, J. (2012). “The Rise of Storytelling as the New Marketing”. Publishing Research Quarterly, 28, 116-123.

Vatan Gazetesi, (2005). Halk sağlı̆̆ için 25 trilyon liralık zararı göze aldı, 07.03.2005, retrieved 15.04.2016, from http://www.gazetevatan.com/halk-sagligi-icin-25-trilyonliralik-zarari-goze-aldi-48628-ekonomi/. 